\title{
Black-white differences in appeal of cigarette advertisements among adolescents
}

\author{
Philip P Huang, Dee Burton, Holly L Howe, Daniel M Sosin
}

\begin{abstract}
Objectives - To identify differences between black and white adolescents in the appeal of cigarette advertisements; to compare the appeal of different kinds of advertisements (cartoons, human models, text only); and to determine what images about smokers and smoking are conveyed to adolescents by different cigarette advertisements.

Design - Students completed an anonymous self administered questionnaire and reported subjective responses to 13 recent cigarette advertisements.
\end{abstract}

Participants - A convenience sample of 243 seventh and eighth grade students (age range 12 to 14 ) attending two junior high schools in the Chicago metropolitan area in 1991.

Results-Advertisements featuring the cartoon character Joe Camel were significantly more appealing to both black and white students than were advertisements with human models and with text only $(p<0.001)$. Text only advertisements were significantly less appealing than other types of advertisements among both black and white students $(p<0.001)$. Two advertisements featuring black models were significantly more appealing to black students than white students $(p=$ 0.03 and $p<0.001$ ). Cigarette advertisements conveyed distinct desirable images about the depicted models to both black and white students: Joe Camel was "cool" and "fun," and female models were "slim" and "good looking."

Conclusion - This study provides further support for the year 2000 national objective to "eliminate or severely restrict all forms of tobacco product advertising and promotion to which youth younger than age 18 are likely to be exposed."

(Tobacco Control 1992; 1 : 249-55)

\section{Introduction}

Cigarette smoking is recognised as the single most important preventable cause of death and disease in the United States. ${ }^{1}$ In 1988 an estimated 434175 premature deaths in the United States were attributable to cigarette smoking. ${ }^{2}$

Cigarette smoking is also a major problem in the black community. Blacks in the United States have smoked at higher rates than whites for each year of the National Health Interview Survey since $1965 . .^{3}$ In addition, the rate of years of potential life lost before age 65 attributed to smoking among blacks (2472 per 100000 population) was twice that for whites (1225 per 100000 population). ${ }^{2}$

The tobacco industry has long claimed that it does not want adolescents to smoke and that cigarette advertising is used only to influence brand selection among adult smokers. ${ }^{4}$ Nevertheless, approximately a half of the adult regular smokers born since 1930 had become regular smokers before their 18 th birthdays. ${ }^{5}$ Marketing research conducted by the tobacco industry notes, "serious efforts to learn to smoke occur between ages 12 and 13 in most cases. "6 National studies show that among all race and ethnic groups, smoking initiation occurs at ages as young as 9 years, increases rapidly from 11 to 16 years of age, and peaks at 17 to 19 years of age.

In 1988, $\$ 3.27$ billion (almost $\$ 9$ million each day) were spent on cigarette advertising and promotion in the United States. ${ }^{8}$ Such expenditures made cigarettes the most heavily advertised product in outdoor media and the second most heavily advertised product in magazines. Both media are readily accessible to children and adolescents. Cigarette advertising and promotional expenditures increased by $10 \%$ to $\$ 3.61$ billion in 1989 . $^{9}$

Evidence that relates cigarette advertising to initiation of smoking by adolescents continues to grow. Studies in Scotland and Australia have shown that children and adolescents were exposed to and were well aware of cigarette advertising, and that underage smokers are more adept than underage non-smokers at recalling, recognising, and identifying cigarette advertisements. ${ }^{10-12} \mathrm{~A}$ recent study found that the advertising campaign featuring the cartoon character, Joe Camel, achieved higher brand recognition, recall, and appeal among high school students than among adults ${ }^{13}$; and comparison of brand preference data obtained before and since introduction of this campaign suggests preferential appeal of the campaign to adolescents. ${ }^{14}$ Another study showed that by 6 years of age children can recognise Joe Camel as easily as Mickey Mouse. ${ }^{15}$

We studied a group of seventh and eighth grade students (age range 12 to 14 ) in the Chicago metropolitan area to examine the appeal of cigarette advertising to adolescents 


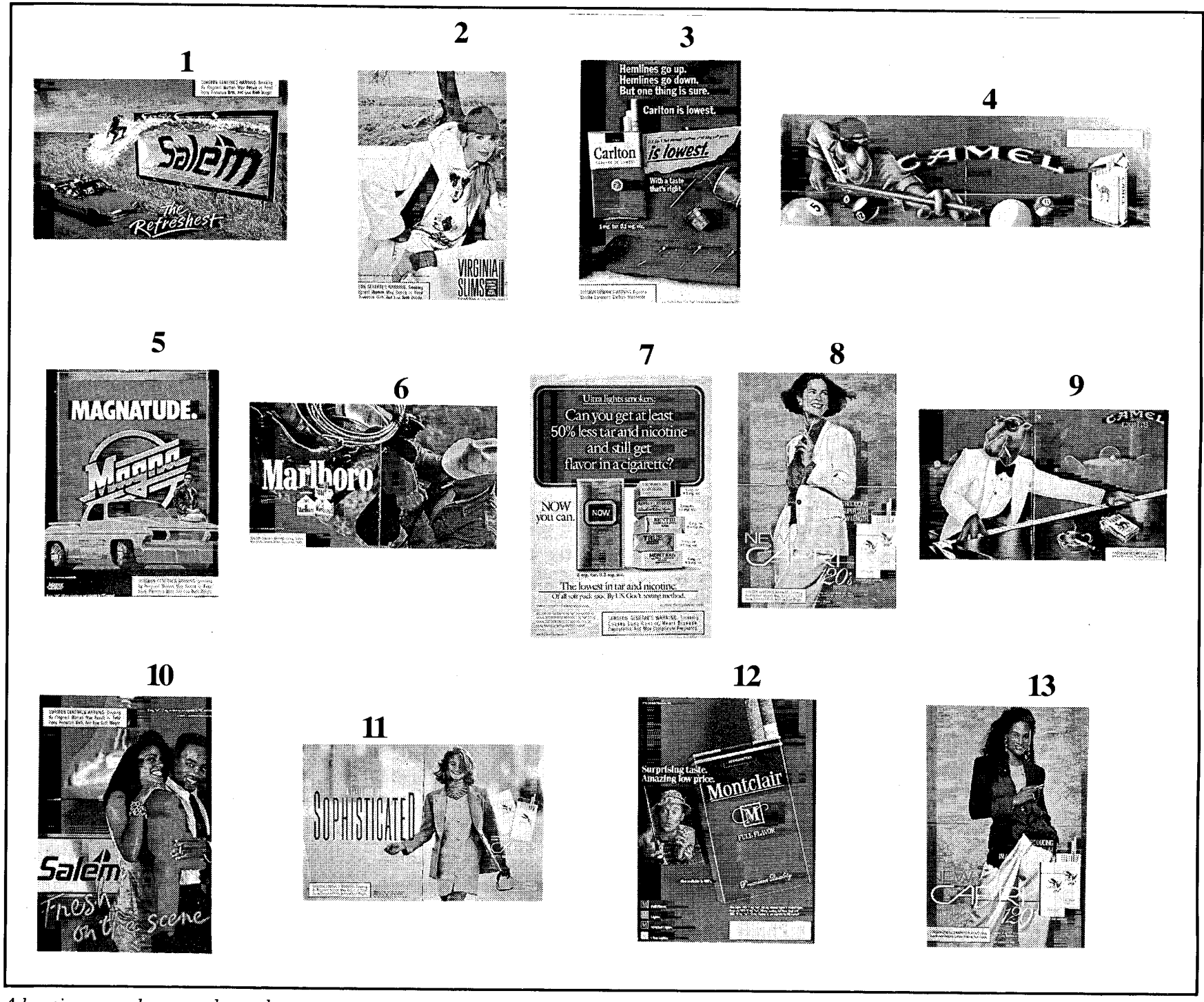

Advertisements shown to the students

and to look at differences between black and white students. In particular, we examined $(a)$ how much exposure adolescents have to cigarette advertisements; (b) differences in the appeal of advertisements according to their style (cartoon, models, text only); (c) differences in the appeal of advertisements according to cigarette brand and race of models; and (d) images conveyed by cigarette advertisements. To our knowledge, this study represents the first report that examines black and white differences in the appeal of cigarette advertisements among adolescents.

\section{Methods}

A cross-sectional survey of students in two junior high schools in the Chicago area was conducted in April 1991. Schools were selected to achieve a racial representation of black and white students. Available seventh and eighth grade classes were identified by each school principal.

All students completed an anonymous, self administered questionnaire that included information about current cigarette smoking practices, the last time they saw an advertisement for cigarettes, their ideal self image, and demographic characteristics. To assess ideal self image, the students were asked to rate on a five point scale their desire to resemble 19 characteristics: athletic, good looking, kind, slim, macho, smart, sexy, average, fun, special, independent, cool, afraid, overweight, underweight, tough, important, mature, and immature.

Students were next shown slides of 13 recent cigarette advertisements (figure). The advertisements represented nine different brands of cigarettes and were obtained from nine different magazines purchased at a supermarket newsstand. Advertisements were selected to represent a variety of styles as well as an assortment of models of different race and sex. The advertisements chosen did not reflect their prevalence in the media.

As they viewed each advertisement, the students were asked: "How much do you like this advertisement?" and "If you smoked, would you like to buy these cigarettes?" For advertisements with human or cartoon models, the students were also asked to rate how strongly the models projected the same 19 characteristics that were used to define ideal self image. Five point scales were used for each of the responses.

After each session, debriefing discussions were conducted with the students for the 
purpose of reviewing the implications of using imagery in cigarette advertising.

\section{DATA ANALYSIS}

To compare mean appeal scores of advertisements featuring cartoon characters with those of advertisements featuring human models and advertisements with text only, each advertisement was categorised into one of these three styles. Differences between these styles were tested using the Wilcoxon signed ranks test.

Black and white differences in the appeal of advertisements were tested using the Wilcoxon two sample test. All 13 advertisements were analysed individually to examine differences by brand of cigarette and race of model.

We hypothesised that variations in the appeal of advertisements might reflect differences in advertisement images. To characterise advertisement images, a principal component analysis with varimax rotation was first conducted to group advertisements with similar appeal. Groups of advertisements (principal components) with eigenvalues $>1.0$ were extracted. The eigenvalue is an indicator of the amount of variance accounted for by each principal component. Advertisements with loadings $>0.6$ were included in each group. The 19 character attributes were ranked according to their mean scores for each group of advertisements. Character attributes were considered to be a desired ideal self image and to be positively attributed to the models if their mean score was $>3.0$ (neutral). Black and white differences in perceived character attributes for each group of advertisements were tested using the Wilcoxon two sample test.

Spearman's rank order correlation coefficients were used to measure correlation between "liking" an advertisement and intention to buy the advertised brand if students smoked.

Data were analysed using Epi $\operatorname{Info}^{16}$ and Statistical Analysis System (SAS) ${ }^{17}$ computer software. Differences were significant when the two tailed $\mathrm{p}$ values were $<0.05$.

\section{Results}

Questionnaires were completed by 243 seventh and eighth grade students. Their mean age was 13.3 years (SD 1.47). Forty-nine per cent were girls and $51 \%$ were boys. Seventy per cent (170) of the students were black, $22 \%(54)$ were white, $3 \%(7)$ were Hispanic, $1 \%$ (2) were Asian, $2 \%$ were native American Indian, and $2 \%(5)$ were of other races. Four per cent (6) of the black students, $11 \%$ (6) of the white students, $43 \%$ (3) of the Hispanic students, and $20 \%$ (1) of the students of "other" races reported that they smoked cigarettes. Because of the small numbers of students in several of the race groups, further analyses were limited to the 224 responses by black and white students.

\section{EXPOSURE TO ADVERTISEMENTS}

Both black and white students reported substantial exposure to cigarette advertising. Thirty six per cent of black students and 35\% of white students reported that they had seen a cigarette advertisement that same day. Eightysix per cent of black students and $85 \%$ of white students reported that they had seen a cigarette advertisement within the previous week.

\section{APPEAL OF ADVERTISEMENTS}

The advertisements ranked in descending order of mean appeal scores are shown in table 1 for black and white students. Regardless of race, the advertisements for Camel cigarettes featuring Joe Camel had the highest mean appeal scores of all of the advertisements tested. For both black and white students the advertisements featuring Joe Camel were significantly more appealing than either advertisements with human models or advertisements with text only $(p<0.001)$. The advertisements with human models were also significantly more appealing than those with text only $(\mathrm{p}<0.001)$. Both advertisements with black models were significantly more appealing to black students than to white students. Advertisement No 10 for Salem cigarettes,

Table 1 Ranking of advertisements by appeal

\begin{tabular}{|c|c|c|c|c|c|c|c|c|c|c|}
\hline \multicolumn{5}{|c|}{ Black students $(n=170)$} & & \multicolumn{5}{|c|}{ White students $(n=54)$} \\
\hline $\begin{array}{c}\text { Advert- } \\
\text { isement } \\
\text { No }\end{array}$ & Brand & $\begin{array}{l}\text { Race } \\
\text { of } \\
\text { model }\end{array}$ & $\begin{array}{c}\text { Mean } \\
\text { appeal } \\
\text { score }\end{array}$ & $\begin{array}{l}\text { Percentage } \\
\text { liking } \\
\text { advert- } \\
\text { isement } \dagger\end{array}$ & Rank & $\begin{array}{c}\text { Advert- } \\
\text { isement } \\
\text { No }\end{array}$ & Brand & $\begin{array}{l}\text { Race } \\
\text { of } \\
\text { model }\end{array}$ & $\begin{array}{l}\text { Mean } \\
\text { appeal } \\
\text { score }\end{array}$ & $\begin{array}{l}\text { Percentage } \\
\text { liking } \\
\text { advert- } \\
\text { isement } \dagger\end{array}$ \\
\hline 9 & Camel & Cartoon & $4 \cdot 2$ & 75 & 1 & 9 & Camel & Cartoon & 4.5 & 81 \\
\hline 4 & Camel & Cartoon & $4 \cdot 0$ & 71 & 2 & 4 & Camel & Cartoon & $4 \cdot 3$ & 78 \\
\hline 10 & Salem & Black & 3.9 & 67 & 3 & 1 & Salem & White & $3 \cdot 6$ & 57 \\
\hline 13 & Capri & Black & $3 \cdot 7$ & 54 & 4 & 11 & Capri & White & 3.6 & 54 \\
\hline 1 & Salem & White & 3.5 & 58 & 5 & 2 & $\begin{array}{l}\text { Virginia } \\
\text { Slims }\end{array}$ & White & $3 \cdot 3$ & 46 \\
\hline 2 & $\begin{array}{l}\text { Virginia } \\
\text { Slims }\end{array}$ & White & $3 \cdot 4$ & 54 & 6 & 6 & Marlboro & White & $3 \cdot 3$ & 46 \\
\hline 8 & Capri & White & 3.4 & 51 & 7 & 8 & Capri & White & $3 \cdot 2$ & 37 \\
\hline 5 & Magna & White & $3 \cdot 3$ & 48 & 8 & 13 & Capri & Black & $3 \cdot 2$ & 43 \\
\hline 11 & Capri & White & $3 \cdot 0$ & 40 & 9 & 10 & Salem & Black & $3 \cdot 0$ & 30 \\
\hline 6 & Marlboro & White & 2.5 & 22 & 10 & 5 & Magna & White & $2 \cdot 9$ & 28 \\
\hline 7 & Now & None & $2 \cdot 0$ & 15 & 11 & 12 & Montclair & White & $2 \cdot 3$ & 22 \\
\hline 12 & Montclair & White & $2 \cdot 0$ & 14 & 12 & 7 & Now & None & 1.8 & 9 \\
\hline 3 & Carlton & None & 1.8 & 11 & 13 & 3 & Carlton & None & 1.6 & 2 \\
\hline
\end{tabular}

$\star 1=$ Do not like at all; $2=$ dislike somewhat; $3=$ neither like nor dislike; $4=$ like somewhat $; 5=$ like very much $\dagger$ Response $=4$ or 5 . 
Table 2 Principal component analysis grouping of advertisements by appeal

\begin{tabular}{|c|c|c|c|c|c|c|c|c|c|c|c|c|c|c|}
\hline \multicolumn{3}{|c|}{$\begin{array}{c}\text { Group 1 } \\
\text { (eigenvalue }=2.65 \text { ) }\end{array}$} & \multicolumn{3}{|c|}{$\begin{array}{c}\text { Group 2 } \\
\text { (eigenvalue }=1.63 \text { ) }\end{array}$} & \multicolumn{3}{|c|}{$\begin{array}{c}\text { Group 3 } \\
\text { (eigenvalue = 1.53) }\end{array}$} & \multicolumn{3}{|c|}{$\begin{array}{c}\text { Group 4 } \\
\text { (eigenvalue }=1.42)\end{array}$} & \multicolumn{3}{|c|}{$\begin{array}{c}\text { Group 5 } \\
\text { (eigenvalue = 1.22) }\end{array}$} \\
\hline $\begin{array}{l}\text { Advert- } \\
\text { isement }\end{array}$ & Brand & $\begin{array}{l}\text { Load } \\
\text { score }\end{array}$ & $\begin{array}{l}\text { Advert- } \\
\text { isement }\end{array}$ & Brand & $\begin{array}{l}\text { Load } \\
\text { score }\end{array}$ & $\begin{array}{l}\text { Advert- } \\
\text { isement }\end{array}$ & Brand & $\begin{array}{l}\text { Load } \\
\text { score }\end{array}$ & $\begin{array}{l}\text { Advert- } \\
\text { isement }\end{array}$ & Brand & $\begin{array}{l}\text { Load } \\
\text { score }\end{array}$ & $\begin{array}{l}\text { Advert- } \\
\text { isement }\end{array}$ & Brand & $\begin{array}{l}\text { Load } \\
\text { score }\end{array}$ \\
\hline 2 & $\begin{array}{l}\text { Virginia } \\
\text { Slims }\end{array}$ & $0 \cdot 72$ & $\begin{array}{l}4 \\
9\end{array}$ & $\begin{array}{l}\text { Camel } \\
\text { Camel }\end{array}$ & $\begin{array}{l}0 \cdot 84 \\
0 \cdot 78\end{array}$ & $\begin{array}{l}3 \\
7\end{array}$ & $\begin{array}{l}\text { Carlton } \\
\text { Now }\end{array}$ & $\begin{array}{l}0 \cdot 77 \\
0 \cdot 64\end{array}$ & $\begin{array}{r}5 \\
10\end{array}$ & $\begin{array}{l}\text { Magna } \\
\text { Salem }\end{array}$ & $\begin{array}{l}0 \cdot 82 \\
0 \cdot 60\end{array}$ & 6 & Marlboro & 0.82 \\
\hline $\begin{array}{r}8 \\
11 \\
13\end{array}$ & $\begin{array}{l}\text { Capri } \\
\text { Capri } \\
\text { Capri }\end{array}$ & $\begin{array}{l}0.68 \\
0.82 \\
0.80\end{array}$ & & & & 12 & Montclair & $0 \cdot 61$ & & & & & & \\
\hline
\end{tabular}

which featured a black couple, had a mean appeal score of 3.86 for black students $v$ a score of 3.04 for white students $(p<0.001)$. Advertisement No 13 for Capri cigarettes, which featured a black female model, had a mean appeal score of 3.68 for black students $v$ a score of 3.20 for white students $(p=0.03)$. These racial differences in appeal do not seem merely to reflect pre-existing brand preferences because advertisement No 11 , also for Capri cigarettes but featuring a white female model, was significantly more appealing to white students than black students (mean appeal score $=3.04$ for black students $v 3.60$ for white students, $p=0.02$ ). The other advertisement for Salem cigarettes (No 1) and a third advertisement for Capri cigarettes (No 8), both featuring white models, did not have significant differences in appeal by race.

Two advertisements featuring white male models also had significant differences in appeal to black and white students. The advertisement for Magna cigarettes (No 5), featuring a white male model sitting on a truck, was significantly more appealing to black students than to white students (mean appeal. score $=3.30$ for black students $v 2.86$ for white students, $\mathrm{p}=0.04)$. The advertisement for Marlboro cigarettes (No 6), featuring a white cowboy model, was significantly more appealing to white students than to black students (mean appeal score $=3.26$ for white $v 2.49$ for black students, $\mathrm{p}<0.001$ ).
Students who reported liking an advertisement were also more likely to report that if they smoked, they would buy the advertised brand (Spearman correlation coefficients $>0.4$ with $\mathrm{p}<0.001$ for all 13 advertisements).

\section{CHARACTER ATTRIBUTES}

Principal-component analysis identified five groupings (principal components) of the advertisements reflecting differences in appeal (table 2). These five groupings accounted for $65 \%$ of the variance in the data. None of the other principal components explained more than $6.3 \%$ of the variance. Advertisement No 1 (Salem) was the only advertisement that did not factor into a group, although it was closer to group two (factor load $=0 \cdot 45$ ).

Attribute scores ascribed to the models are shown for advertisement groupings by race in table 3 . Each positive model attribute (mean score $>3.0$ ) in table 3 had also been reported to be a desirable ideal self image characteristic by the students (mean score $>3.0$ ). Distinctive images were conveyed by the different groups of cigarette advertisements. When attributes with mean scores $\geqslant 4$ were analysed, the female models (group 1) were viewed as slim and good looking by both black and white students, and Joe Camel (group 2) was viewed as cool and fun. The black couple and the Magna male model (group 4) were perceived to be cool by the black students while white

Table 3 Mean attribute scores by race for principal component groups ${ }^{\star}$

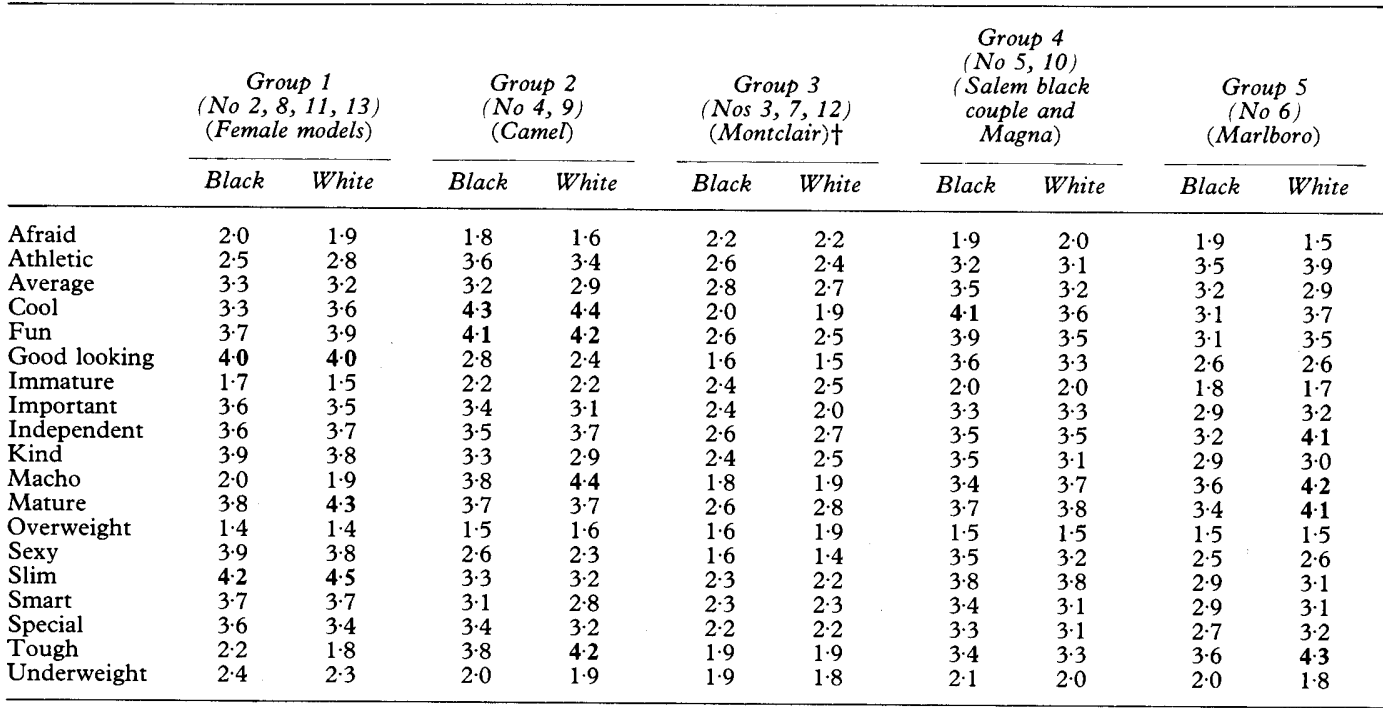

$\star 1=$ Not at all like this; $2=$ not much like this; $3=$ neither like nor unlike this; $4=$ a little like this; $5=$ just like this. † Scores reflect responses to advertisement No 12 only.

Scores $\geqslant 4.0$ are shown in bold. 
students thought the Marlboro man (group 5) was tough, macho, independent, and mature. Unlike the other advertisement groups, the male Montclair model (group 3) had no attributes positively ascribed to him.

Compared with white students, black students thought that the black couple and the male Magna mi del (group 4) were significantly more cool $(\mathrm{p}<, .01)$, fun $(\mathrm{p}=0.02)$, kind $(\mathrm{p}=$ $0.01)$, sexy $(\mathrm{p}<0.05)$, and smart $(\mathrm{p}=0.03)$. In contrast, white students thought the female models (group 1) were more mature ( $p=0.02$ ) and that the Marlboro man (group 5) was more macho $(\mathrm{p}=0.02)$, tough $(\mathrm{p}<0.01)$, independent $(\mathrm{p}<0.001)$, cool $(\mathrm{p}=0.02)$, and special $(p=0.03)$ than did black students. No other attributes showed significant differences by race.
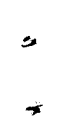

$=$

\section{Discussion} market research measure which has been shown to be strongly related to effect on sales. A recent study performed by the Advertising Research Foundation found likability (measured by a scale similar to that used in this study) to be the best predictor of product sales when compared with the other commonly used measures to evaluate the effectiveness of an advertisement. ${ }^{18}$

Our study found that regardless of race, the cigarette advertisements with a cartoon character (Joe Camel) were highly appealing to adolescents. Previous studies have suggested that exposure to the images of models in cigarette advertisements promotes positive images of smokers and that adolescents, although developing their own self image, may be drawn towardis smoking as a way of enhancing their self images. ${ }^{19,20}$ As Joe Camel was appealing to the students and perceived as embodying attributes desirable to the students, we believe that this advertising campaign might contribute to initiating cigarette smoking, especially the smoking of Camel cigarettes, by adolescents.

Public health experts have recommended restriction of advertising to "tombstone advertising" in which no models, slogans, scenes, or colours are permitted. ${ }^{21}$ This study presents empirical evidence that shows a lack of appeal to adolescents of cigarette advertisements with text only. The text only advertisements used in this study approach the criteria of the proposed tombstone advertising.

Only among the cigarette advertisements with human models were significant differences in appeal noted between black and white students. Cummings et al previously noted a relation between placement of advertisements for menthol brands in black-oriented media and preference among black adults for menthol brands. ${ }^{22}$ To our knowledge, our study is the first to show that targeting of cigarette brands to blacks through using advertisements featuring black models also preferentially appeals to black adolescents.

Another black and white difference identified in this study was the significantly higher
The appeal of advertisements (likability) is a appeal of the Marlboro advertisement among white students than among black students. The black students found the Marlboro man to be unappealing. We hypothesise that a lack of cultural identification with the cowboy image may exist among black students, making this campaign less appealing. National data for 1989 indicate that $71 \%$ of white adolescent smokers usually bought Marlboro cigarettes, whereas only $9 \%$ of black adolescent smokers chose Marlboro. ${ }^{23}$

Limitations of this study should be addressed. Firstly, this study used a convenience sample rather than a representative sample of students from throughout the United States. We have shown, however, that these advertisements are appealing to some adolescents, and we have no reason to believe that this appeal is not widespread. Secondly, the selection of the advertisements used in the study was arbitrary. Different advertisements for the same brand but featuring the same models may vary in their appeal to adolescents. All of the advertisements selected, however, could be readily viewed by adolescents and children.

Our study suggests that both black and white adolescents are exposed to cigarette advertising, that they find many cigarette advertisements appealing, and that desirable images about smokers and smoking are conveyed through the advertisements. Given the known adverse health effects of smoking, and the importance of preventing adolescents from starting to smoke, one could argue that the burden of proof should be placed on the tobacco industry to show that their advertisements have no adolescent appeal and that they do not convey misleading messages.

One of the national health promotion and disease prevention objectives for the year 2000 is to "eliminate or severely restrict all forms of tobacco product advertising and promotion to which youth younger than age 18 are likely to be exposed" (objective 3.15). ${ }^{24}$ Results from this study provide further support for pursuing this objective.

We are indebted to Masarrath Moinuddin for her help in recruiting the participating schools, Nancy Barker for statistical consultation, and Dan Peterson for reviewing the manuscript. We also thank the students and administration at the junior high schools where this research was conducted.

1 US Department of Health and Human Services. The health benefits of smoking cessation: a report of the Surgeon General, 1990 . A Control, Office on Smoking and Health, 1990. (DHHS Publication No (CDC) $90-8416$.

2 Centers for Disease Control. Smoking-attributable mortality and years of potential life lost - United States, tality and years of potential life lost
1988. $M M W R$ 1991; 40:62-3,69-71.

3 Centers for Disease Control. Cigarette smoking among blacks and other minority populations. $M M W R$ 1987; 36: 404-7.

4 RJ Reynolds Tobacco Company. We don't advertise to children [advertisement]. Time 1984 Apr 9: 91

5 Centers for Disease Control. Difference in the age of smoking initiation between blacks and whites - United States. MMWR 1991; 40: 754-7.

6 Pollay RW. The functions and management of cigarette advertising. Quebec Superior Court, Imperial Tobacco advertising. Quebec Superior Court, Imperial Tobacco Ltd and RJR-Macdonald Inc $v$ Le Procureur General du

7 Escobedo LG, Anda RF, Smith PF, Remington PL, Mast 
EE. Sociodemographic characteristics of cigarette smoking initiation in the United States: implications for ing initiation in the United States: implications for smoking prevention policy. f $A M A$ 1990; 264: 1550-5.
8 Centers for Disease Control. Cigarette advertising - United Centers for Disease Control. Cigarette advert
States, 1988. MMWR 1990; 39: 261-5.

9 US Federal Trade Commission. Federal Trade Commission report for 1989. Pursuant to the Federal Cigarette Labeling and Advertising Act. Tobacco Control 1992; 1 : 73-7.

10 Aitken PP, Leather DS, O'Hagan FJ, Squair SI. Children's awareness of cigarette advertisements and brand imagery. $\mathrm{Br} \mathcal{F}$ Addict $1987 ; 82: 615-22$.

11 Chapman S, Fitzgerald B. Brand preference and advertising recall in adolescent smokers: some implications for health promotion. Am f Public Health 1982; 72: 491-4.

12 Aitken PP, Eadie DR. Reinforcing effects of cigarette advertising on underage smoking. Br $\mathcal{F}$ Addict $1990 ; 85$ : 399-412.

13 DiFranza JR, Richards JW, Paulman PM, Wolf-Gillespie N, Fletcher C, Jaffe RD, Murray D. RJR Nabisco's cartoon camel promotes car

14 Pierce JP, Gilpin E, Burns DM, Whalen E, Rosbrook B, Shopland $\mathrm{D}$, et al. Does tobacco advertising target young people to start smoking? Evidence from California. fAMA 1991; 266: 3154-8.

15 Fischer PM, Schwartz MP, Richards JW, Goldstein AO, Rojas TH. Brand logo recognition by children aged 3 to 6 years: Mickey Mouse and Old Joe the Camel. f $A M A$ $1991 ; 266$ : 3145-8.
16 Dean AG, Dean JA, Burton AH, Dicker RC. Epi Info, version 5: a word processing, database, and statistics version : a word processing, database, and statistics program for epidemiology on microcomputers. Atianta,

17 SAS II

AS Institute. Version 5 SAS software. Cary, North Carolina: SAS Institute, 1985

18 Haley RI, Baldinger AL. The ARF copy research validity project. Fournal of Advertising Research 1991; 31: 11-32. 19 Burton D, Sussman S, Hanson W, Johnson CA, Flay BR. Image attributions and smoking intension among seventh grade students. Fournal of Applied Social Psychology 1989; 19: 656-64.

20 Barton J, Chassin L, Presson CC, Sherman SJ. Social image factors as motivators of smoking initiation in early and middle adolescence. Child Dev 1982; 53.1449-511.

21 Warner KE. Selling smoke: cigarette advertising and public health. Washington, DC: American Public Health Association, 1986: 91-2.

22 Cummings KM, Giovino G, Mendicino AJ. Cigarette advertising and black-white differences in brand preadvertising and black-white differences in brand pre-

23 Centers for Disease Control. Comparison of the cigarette brand preferences of adult and teenaged smokers brand preferences of adult and teenaged smokers -
United States, 1989, and 10 US communities, 1988 and 1990. MMWR 1992; 41: 169-73, 179-81.

24 US Public Health Service. Healthy people 2000 : national health promotion and disease prevention objectives. Washington, DC: US Department of Health and Human Services, Public Health Service, 1991. (DHHS Publication No (PHS)91-50212.) 
Translations Différences entre blancs et noirs quant à of abstract l'attirance des adolescents pour les publiciteś pour les cigarettes
Philip P Huang et al

\section{Résumé}

Objectifs: Identifier les différences entre les adolescents noirs et les adolescents blancs quant à l'attirance pour les publicités pour les cigarettes; comparer l'attirance exercée par différents types de publicité (bandes dessinées, modèles humains, texte); et determiner les images du fumeur et du tabagisme qui sont communiquées aux adolescents par différentes publicités pour les cigarettes.

Méthode: Les étudiants ont rempli eux-mêmes un questionnaire anonyme et ont fait part de leur réactions subjectives à 13 publicités récentes pour les cigarettes. Participants: Un échantillon de 243 étudiants des niveaux 7 et 8 (âgés de 12 à 14 ans) qui fréquentaient deux lycées de la zone urbaine de Chicago en 1991.

Résultats: Les publicités représentant le personnage de bande dessinée Joe Camel attiraient significativement plus les étudiants blancs et noirs que les publicités représentant des modèles humains et celles qui ne comportaient qu'un texte $(\mathrm{p}<0.001)$. Les publicités qui ne comportaient qu'un texte attiraient significativement moins les étudiants blancs et noirs que les autres types de publicité $(\mathrm{p}<0.001)$. Deux publicités représentant des mannequins noirs étaient significativement plus attirantes pour les élèves noirs que pour les élèves blancs ( $p=0.03$ et $p<0.001)$. Selon les modèles représentés, les publicités pour les cigarettes communiquaient aux étudiants blancs et noirs des images désirables distinctes: Joe Camel était "cool" et "fun" et les mannequins féminins étaient "minces" et "belles."

Conclusion: Cette étude apporte un nouveau soutien pour l'objectif national de l'an 2000 qui est "d'éliminer ou de sévèrement restreindre toute forme de publicité et de promotion pour les produits du tabac auxquelles les jeunes de moins de 18 ans sont susceptibles d'etre exposés."

\section{Diferencias en el atractivo de los anuncios de cigarrillos para los adolescentes negros y los blancos}

Philip Huang et al

\section{Resumen}

Objetivos: Identificar las diferencias en el atractivo de los anuncios de cigarrillos para los adolescentes negros y los blancos; comparar el atractivo de diferentes clases de anuncios (caricaturas, modelos humanos, texto solo); $\mathrm{y}$ determinar qué imágenes acerca de los fumadores y el tabaquismo se transmiten a los adolescentes por los diferentes anuncios.

Diseño: Los estudiantes respondieron por sí solos un cuestionario anónimo y expresaron sus respuestas subjetivas a 13 anuncios de cigarrillos recientes. Participantes: Muestra de conveniencia de 243 estudiantes de séptimo y octavo grados (intervalo de edades: 12 a 14 años) que asistían a dos escuelas secundarias en la zona metropolitana de Chicago en 1991.

Resultados: Los anuncios que presentaban la caricatura conocida como Joe Camel eran significativamente más atractivos para los alumnos blancos y los negros que los que presentaban modelos humanos y texto solo $(\mathrm{p}<$ $0,001)$. Los anuncios basados únicamente en textos fueron significativamente menos atractivos que los otros tipos para los estudiantes blancos y los negros ( $\mathrm{p}<$ $0,001)$. Dos anuncios que presentaban modelos negros fueron significativamente más atractivos para los adolescentes negros que para los blancos $(p=0,03$ y $p<$ $0,001)$. Los anuncios de cigarrillos transmitian imágenes claramente atrayentes acerca de los modelos tanto a los muchachos negros como a los blancos: Joe Camel era "un gran tipo" y "divertido", y las modelos eran "esbeltas" y "bonitas".

Conclusion: Este estudio proporciona apoyo adicional al objetivo nacional para el año 2000 consistente en "eliminar o restringir intensamente todas las formas de publicidad y promoción de los productos de tabaco a las que puedan verse expuestos los menores de 18 años".

\section{卷烟广告对黑人青少年和白人贵少年吸引力的区别 菲利浦・黄}

研究目标：调查卷烟广告对黑人青少年和白人青少年的吸引力的区别; 比较不同类型卷烟广 告 (动画、人物模特和单纯文字材料) 的吸引力, 并确定不同类型卷烟广告给青少年提供的 信息和形象

研究设计：学生填写一份不记名调查表, 并填写他们对最近 13 种卷烟广告的反应。

研究对象: 芝加哥市区两所初级中学 243 名 (12 岁至 14 岁) 七年级和八年级 1991 年的任校 学生。

研究结果: “骆驼老乔” 广告在黑人和白人学生中产生的吸引力明显高丁人物模特和单纯文 字材料的吸引力 $(\mathrm{P}<0.001)$ 单纯文宁材料产生的吸引力明显低丁其他种类的广告。两个黑 人模特的广告对黑人学生的吸引力明显高丁对白人学尘的吸引力 $(\mathrm{P}=0.03$ 和 $\mathrm{P}<0.001)$ 卷 烟广告在黑人学生和白人学生中都产生了吸人注目的形象。“骆驼老乔”给人们的印象是 “好极了” “好玩”，女性模特给人的印象是 “秀气” 和“美丽”。

研究结论：2000 年国家目标之一是 “禁止或严格限制计对 18 岁以下青少年的卷烟广告”，本 研究为该目标提供了进一步的支持。 